\title{
1516 受動車輪型移動機構を用いたニ足ロボットの倒立に関する研究 Study on handstand of two-legged robot with passive wheel
}

\author{
○学 新谷和也（高知工科大学院） 正 井上喜雄（高知工科大学） 正 芝田京子（高知工科大学） \\ 学 上田雄介（高知工科大学院）学 瀬川靖彦（高知工科大学）
}

\begin{abstract}
Akihiro KIMURA, Kochi Univ. of Technology, Tosayamada-cho, Kami-shi, Kochi 782-8502, Japan Yoshio INOUE, Kochi Univ. of Technology, Kyoko SHIBATA, Kochi Univ. of Technology Yusuke UEDA, Kochi Univ. of Technology, Yasuhiko SEGAWA, Kochi Univ. of Technology
\end{abstract}

Key word : Biped robot, passive wheel, inertia rotor, handstand

\section{1. 緒言}

現在さまざまな環境下で活躍するロボットが多く開発さ れてきており，そのロボットによる移動方法として脚によ る移動や車輪による移動があげられるが，なかでも脚歩行 は段差や不整地など様々な地形に対応した移動が可能であ り，不整地に执ける移動は車輪による移動に比べ効率が良 い。しかし，障害の無い水平面上における移動性能におい ては車輪走行に優位性があると知られている。そこでその 両方の利点を生か寸ために不整地では脚歩行, 整地では車 輪走行と使い分ける八イブリットな移動手法を持つロボッ トが研究されている。この方法としてモーターを持たない 受動車輪を用いて車輪走行を実現する方法が研究されてい るが(1)，その多くは多脚であり二足のロボットはあまり研 究されていない.

本研究では, 環境に合わせて受動車輪による車輪走行と 二足歩行を使い分け移動を行う二足のロボットの開発を目 指してきた。本論文ではこのロボットの車輪走行時におけ る倒立および自立走行の検討とシミュレーションについて 報告する。

\section{2. 受動車輪型移動機構}

本研究で使用した 2 足ロボットの概略図を図 1 (a)に示 す。このように人の足の動作で用いられる股の開閉と足の ひねり機構のみで移動する。
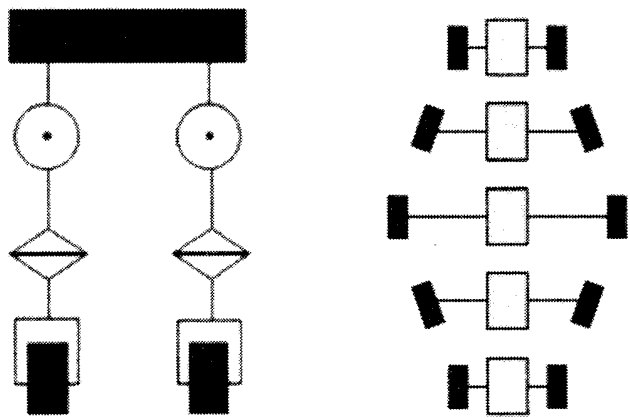

(a) Schematic diagram (b) Movement image of Robot Fig. 1 Biped robot

図1(b)のように，(1)から(5)へと動か寸ことで，ロボッ 卜は図下向きの速度を得る。逆に，(5) から（1）へと足を動 かすことで，図上向きの速度を得る。また，片足を(1)から (5)，もう一方を(5)から (1) へと動かすことで左右の脚が逆 向きの速度を得てその場で回転する。片足の車輪のみ(1) から（5）または（5）から(1)と動かすことで，車輪を動かさ
ない足を軸足とした回転を行う。

\section{3. 受動車輪による推進}

図 2 のように, 車輪が- $\mathrm{L}(\mathrm{t})$ 方向に動く時, 車輪には, 車輪回転の接線方向に Fn，法線方向に Ft が発生する。本 体速度を V とする時，Ft，Fn牥次の式で表される。

$F t=-\operatorname{sgn}(V \times \cos \theta(t)+\dot{L}(t) \times \sin \theta(t)) \times \mu t \times W / 2$

$F n=-\operatorname{sgn}(V \times \sin \theta(t)-\dot{L}(t) \times \cos \theta(t)) \times \mu n \times W / 2$

ここで，Wはロボットの重量である。 $\mathrm{L}(\mathrm{t})$ は，時刻 $\mathrm{t} に お ~$ ける股の開閉速度を表している， $\mu \mathrm{t}$ は，車輪回転方向の ころがりの動摩擦係数であり， $\mu \mathrm{n}$ は，車輪回転軸の法線 方向への動摩擦係数である。また，sgn は括弧内の符号を 監視する関数であり，マイナスであればー1，プラスであれ ば 1 を返す。本体速度 $\mathrm{V}$ と，Fn，Ftの $\mathrm{y}$ 成分を合成し本体 質量Mで割ったものが加速度となり，移動が可能となる。

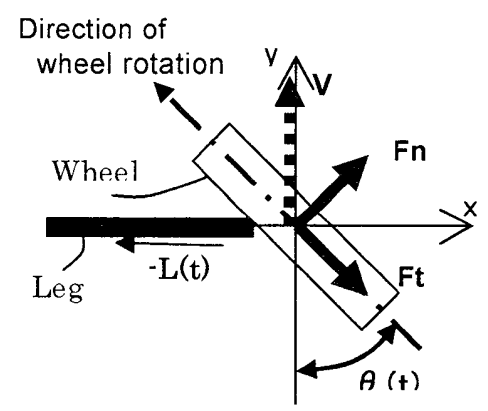

\section{4. 推進条件と推進効率}

Fig. 2 Relation of power

受動車輪による推進力はFt，Fn，日によってきまる。そ の推進力 Fy の式は以下のようになる.

$$
F y=F n \times \sin \theta(t)-F t \times \cos \theta(t)
$$

このように推進力を大きくするには Fn をなるべく大きく Ft をなるべく小さくす礼ばいいことが分かる．先の式 （1）(2）とあわせて考えると，力の上限は摩擦係数と車体荷 重によって決まるため車輪回転方向摩擦係数 $\mu \mathrm{t}$ をなる心゙ く小さく, 車輪回転接線方向摩擦 $\mu \mathrm{n}$ をなる心゙く大きくす る事で推進力の上限を大きくすることができる，なお，推 進可能となる条件は (1) (2) (3) 式より

$$
|\tan \theta(t)| \geq \mu t / \mu n
$$

また， $\mathrm{x}$ 方向の力は

$$
F x=F n \times \cos \theta(t)+F t \times \sin \theta(t)
$$

となり，図 1(b)のようにもう一方の足を左右対称に動かす 
ことで相殺し, y 方向推進力だけを取り出すことが出来る.

\section{5. 受動車輪による倒立}

まずロボットを簡単なモデルで考えると図 3(a)のような 台車型倒立振子のモデルで表わす事ができる．この場合台 車に与える力 Fがこのロボットの移動推進力および制御入 力となるが, 先の式(3)よりこの系の運動方程式は以下のよ うになる。

$$
\begin{aligned}
& (M+m) \ddot{x}_{0}+m l\left(\ddot{\alpha} \cos \alpha-\dot{\alpha}^{2} \sin \alpha\right)=F y \\
& \frac{4}{3} m l^{2} \ddot{\alpha}+m l \ddot{x}_{0}-m g l \alpha=0
\end{aligned}
$$

ここで $\mathrm{M}$ は車体質量， $\mathrm{m}$ は振子質量， 1 は振子長さ， $\alpha$ は 振子傾き角度である。このような運動系の静止時の安定化 については足先の車輪角度 $\theta$ を固定する事で可能であると シミュレーションにおいて示されている(2)。しかし，車体 が運動する場合，先の 2 章で述べたように足先の車輪と股 の開閉を周期的に行い移動するため， $\theta$ が振動的に変化す る. 足先車輪を振動的に変化させる場合, 式(4)上り必ず推 進力を得る事が出来ない場所が存在する. そのため制御入 力Fy がなくなり，制御が不安定になる。このため，この系 の運動時忙足先以外の制御入力が必要であると考える.

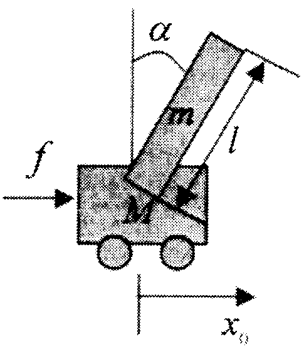

(a) No rotor

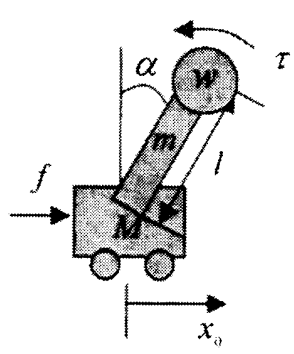

(b) Add rotor
Fig. 3 Cart-pendulum system

\section{6. 慣性ロータによる制御}

ここでその制御入力の一つとして慣性ロータによるトル ク入力を考える.この慣性ロータは図 3 (b) のように取り付 ける。この運動系についてシミュレーションを行なった。 その結果，振子は安定し，ロータの回転角速度も収束した ためこのまま自立走行可能であると考えられる（図 4 ）.

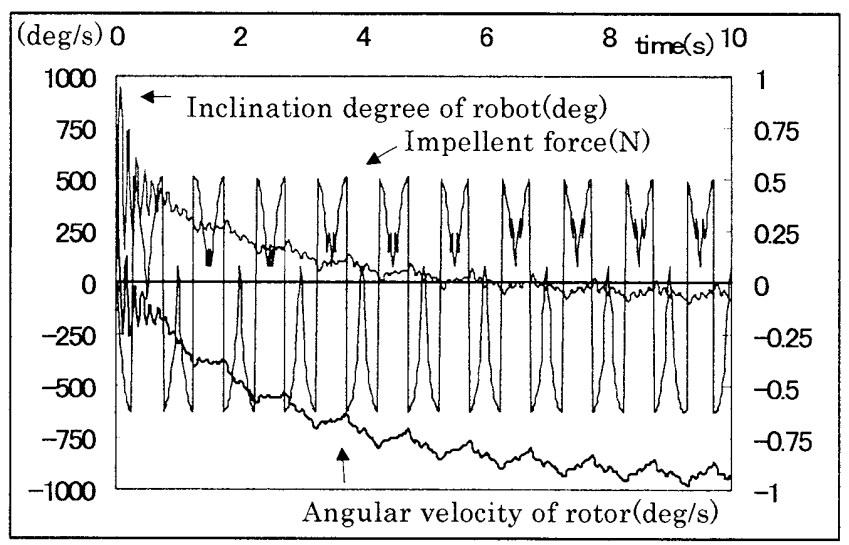

Fig. 4Inertia rotor system

このように慣性ロータを用いる事で簡単なモデルでの自 立走行は可能であると言えるが，このモデルは図 1 (b) に 見られるような走行時における脚の開閉にともなう胴体部 の上下動を考えていない。この胴体部の上下動作は式
（1）(2）のWが変わることで推進力が変化する，重心が移動 するため制御トルクや重量による影響が変化する，胴体の 上下動による慣性力が閉脚時には傾きを増大する方向に開 脚時には傾きを抑制する方向に作用する(図 5)などの影響 を及ぼすと考えられる。

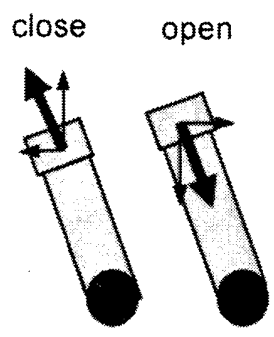

Fig. 5 Inertial force

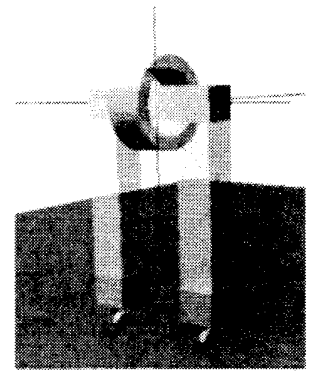

Fig. 6 Simulation model つぎに実際の 2 足ロボットの形をモデルとしたシミュレ ーションを行なった（図 6)。慣性ロータのトルク值を胴体 の傾き角度, 角速度, ロータの回転角速度をフィードバッ クすることによって制御し，自立走行を行なった。その一 例を図 7 に示す。このシミュレーション結果より，脚の閉 脚時に傾きやロータの角速度が大きく变化している事が見 て取れる。このため，開閉動作をフィードバック制御に組 み込めばより安定した自立走行が可能であると考えられる. 今回の一例では慣性ロー夕の角速度は土2000 deg/s の範囲 をとるが，これは慣性ロ一タの形状や重量の調整，開閉動 作のフィードバックで小さくする事が可能であると考える.

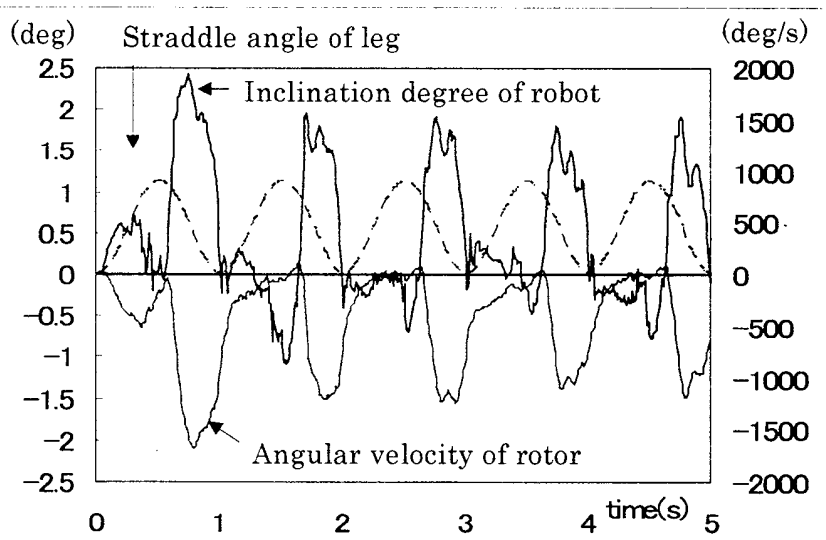

Fig. 7Self-sustained movement

\section{7. 結言}

片足一輪雨足 2 輪の受動車輪を用いた 2 足ロボットにお ける，倒立および自立走行について検討した。それにより 受動車輪の推進力による制御の問題性，慣性ロー夕による 制御の可能性，自立走行時の制御における脚の開閉動作に 対する考慮の必要性を確認する事ができた。

今後の課題として，脚の開閉動作をフィードバックに加 え，慣性ロータの形状や重量を調整する事で安定した自立 走行を行なう事を目指す。

\section{文献}

（1）広瀬茂男・竹内裕喜：ローラーウォ一力: 新しい脚車 輪ハイブリッド移動体の提案, 機論, 62 巻, 599 号, C 編, pp242-248, 1996

（2）上田雄介・新谷·井上·芝田：受動車輪を用いた 2 足口 ボットの研究, 日本機械学会中国四国学生会第 37 回 学生員卒業研究発表講演会講演前刷集, pp.271, 2008 